\title{
Mass wasting at the base of the south central Chilean continental margin: the Reloca Slide
}

\author{
D. Völker ${ }^{1}$, W. Weinrebe ${ }^{1}$, J. H. Behrmann ${ }^{1,2}$, J. Bialas ${ }^{2}$, and D. Klaeschen ${ }^{2}$ \\ ${ }^{1}$ SFB574, IFM-GEOMAR Leibniz Institute for Marine Sciences at the University of Kiel, Wischhofstr. 1-3, Kiel, Germany \\ ${ }^{2}$ Marine Geodynamics, IFM-GEOMAR Leibniz Institute for Marine Sciences at the University of Kiel, Wischhofstr. 1-3, \\ Kiel, Germany
}

Received: 26 March 2009 - Revised: 27 September 2009 - Accepted: 1 October 2009 - Published: 14 December 2009

\begin{abstract}
Offshore south central Chile $\left(35^{\circ} \mathrm{S}-42^{\circ} \mathrm{S}\right)$, the morphology of the lowermost continental slope and trench floor witnesses a voluminous submarine mass-wasting event. The blocky slide body deposited in the Chile Trench at $73^{\circ} 46^{\prime} \mathrm{W} 35^{\circ} 35^{\prime} \mathrm{S}$ was targeted for study during RRS JAMES COOK Cruise JC23 and termed Reloca Slide. Its size of about $24 \mathrm{~km}^{3}$, its steep and high headscarp, the spatial distribution of slide deposits and the cohesive nature of major slide blocks make it interesting to address the issue of tsunami generation. We have obtained seismic reflection data that partly reveal the internal structure of the slide body. Gravity core samples were retrieved that will allow the slide to be dated and linked to the history of sedimentation and slope stability along this particular segment of the Chilean convergent margin. At present we assume a Holocene age for the sliding event.
\end{abstract}

\section{Introduction}

Landslides at submarine slopes are detectable in swath bathymetry data that reveal their characteristic morphological features, for example displaced and rotated blocks, debris flow deposits, headscarps and slump scars. The spatial distribution and the dimensions of these attributes can be used to describe the physics of the failure process and the rheology of the failed slope material. Estimates of the volumes of failed masses, important for calculations of the potential tsunami effect, can be made using reconstructed surfaces with digital elevation models. Other attributes such as the amount of

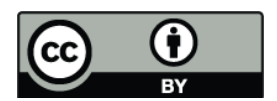

Correspondence to: D. Völker (dvoelker@ifm-geomar.de) internal deformation and the physical nature of the gliding plane, can be derived from seismic reflection data and direct geological sampling at the exposed failure scarp. Geological sampling of debris flow deposits related the slide and the hemipelagic sediment cover postdating the event can permit to date the event and tie it to the tectonic and climatic history of the region.

Here, we combined swath bathymetric data as well as backscatter information of a number of geo-marine surveys to map and identify the large and smaller scale morphological characteristics of the Reloca Slide. These are interpreted in terms of the displacement process and the rheology of the failed lowermost slope material. A volume calculation of the displaced mass resting in the trench, respectively missing at the lower continental slope is presented. A first and cautious estimation of the possible consequence of the sliding event in terms of initial tsunami wave height is given, using equations of Watts et al. (2003). Also, we try to set limits to the age of the Reloca Slide emplacement, based on a reflection seismic profile and gravity core samples.

\section{Geologic setting}

1. The continental margin of Chile north of the Chile Triple Junction $\left(46^{\circ} \mathrm{S}\right)$ is formed by the subduction of the Nazca Plate beneath the South American Plate. The plates converge at about $70 \mathrm{~mm} / \mathrm{yr}(70 \mathrm{~km} / \mathrm{myr})$ at a slightly oblique angle to the $\mathrm{NE}\left(\sim 81^{\circ}\right.$ Angermann et al., 1999). According to some authors, this oblique motion has led to the formation of a forearc sliver (the Chiloé Microplate) that is decoupled from the back arc and moves northward (Melnick et al., 2009). 
2. The floor of the Peru-Chile Trench between the Juan Fernandez Ridge at $32^{\circ} \mathrm{S}$ and the Chile Ridge at $46^{\circ} \mathrm{S}$ is generally flat due to flooding by turbidites. There is an $\mathrm{S}-\mathrm{N}$ increase of water depth $\left(3300 \mathrm{~m}\right.$ at $46^{\circ} \mathrm{S}$ to $5400 \mathrm{~m}$ at $32^{\circ} \mathrm{S}$ ). In line with this gradient, there is a general $\mathrm{S}-\mathrm{N}$ transport and redistribution of sediment, supported by a $1-2 \mathrm{~km}$ wide and $50-150 \mathrm{~m}$ deep, erosional trench axial channel that originates from the Chacao Canyon at $41^{\circ} \mathrm{S}$, and is connected to the exits of large submarine Canyon systems (Thornburg and Kulm, 1983; Thornburg et al., 1990; Laursen and Normark, 2002; Völker et al., 2006). The thickness of the sediment fill of the Peru-Chile Trench axis is $\sim 2 \mathrm{~km}$ in this segment.

3. This sediment fill nourishes the growth of a frontal accretionary prism (Bangs and Cande, 1997; Ranero et al., 2006). In the trench, adjacent to the lowermost slope seismic reflection data reveal a set of reverse faults. The thrust faults develop at depth, and some of them reach the sea floor crosscutting the entire trench fill sequence. Between $37.6^{\circ} \mathrm{S}$ and $38.3^{\circ} \mathrm{S}$, and between $33.2^{\circ} \mathrm{S}$ and $34.5^{\circ} \mathrm{S}$ these faults have a surface expression as they form a succession of sedimentary ridges that strike parallel to the trench axis. They are interpreted as compressive ridges of trench deposits at the base of the continental slope, documenting the trench-ward growth of the recent accretionary prism (Völker et al., 2006; ContrerasReyes et al., 2008).

4. The internal structure of the margin wedge, the lack of an accretionary wedge of Mesozoic and Tertiary age, as well as the Neogene eastward migration of the volcanic arc at $33-37^{\circ} \mathrm{S}$ indicate that the present phase of accretion has not been consistently maintained in the past, and may just have started since the Pliocene, coincident with southern-hemisphere glaciation (Bangs and Cande, 1997; Kukowski and Oncken, 2006). It has been speculated that the onset of accretion, as well as the related change in kinematics, observed in the main Andean Cordillera and the fore-arc basins was related to the glacially controlled increase of sediment flux to the trench (Kukowski and Oncken, 2006; Melnick and Echtler, 2006).

5. Landward of about $30 \mathrm{~km}$ from the wedge tip, the margin wedge is considered old continental basement that possibly acts as a structural backstop for recent frontal accretion. This basement is interpreted to be the seaward continuation of a Late Paleozoic metamorphic complex exposed on land in the Coastal Cordillera (Glodny et al., 2006; Reichert, 2002). The complex (the Eastern and Western metamorphic Series) is seen as a Permo-Triassic accretionary wedge (Glodny et al., 2005; Willner et al., 2005; Hervé et al., 2007). The transition from the present accretionary wedge to continental basement to can be imaged as a steep lateral velocity gradient (Contreras-Reyes et al., 2008) and as a major step in surface heat flow data (Grevemeyer et al., 2003, 2006). In seismic reflection profiles and the respective line-drawings, this transition is not well imaged, but drawn as a steep, landward-inclined boundary (Diaz-Naveas, 1999; Grevemeyer et al., 2006; Reichert, 2002).

6. Seismic reflection data across the margin wedge show that a laterally varying part of the sediment stack is carried to depth within a subduction channel (Bangs and Cande, 1997; Diaz-Naveas, 1999). Whether this sediment input is accreted basally and is responsible for coastal uplift in places (Lohrmann et al., 2006; Melnick and Echtler, 2006) or carried deeper into the subduction zone (e.g. Krawczyk et al., 2006) is a present matter of research. Evidently, coastal uplift rates, which may indicate underplating (Rehak et al., 2008), and the proposed thickness of subducted sediment in the subduction channel change drastically over distances of less than $100 \mathrm{~km}$ (Bangs and Cande, 1997).

7. Sediment input to slope and trench is presently mainly fluvial (Lamy et al., 1998, 1999) and the major river systems have created submarine canyons, probably during sea level low-stands. As the submarine canyons form "drainage" networks that reach up to the upper slope or even connect to river mouths, they funnel sediment into the trench where submarine fans have formed at the canyon exits (Thornburg et al., 1990). The canyon systems are latitudinally spaced at distances of 50$150 \mathrm{~km}$ and form steep-walled, v-shaped gullies that cut as deep as $1000 \mathrm{~m}$ into the margin wedge (Hagen et al., 1996; Laursen and Normark, 2002; Völker et al., 2006). Although much of the downslope sediment transport is concentrated in the canyons, the slope is mantled by slope deposits that thicken in basinal depressions (Raitzsch et al., 2007; Contardo et al., 2008).

8. The continental slope segments between the submarine canyon systems show a number of steep escarpments (up to $30-40^{\circ}$ inclination) as well as platforms and regions that are inclined landwards. While some of the escarpments seem to be surface expressions of deepreaching faults, others show properties related to mass failure. We counted 59 individual mass wasting features on the continental slope between $32^{\circ} \mathrm{S}$ and $46^{\circ} \mathrm{S}$.

9. Sedimentation rate estimates for the region are sparse: (a) for the seaward side of the trench, rates were determined at ODP leg 202 (Shipboard Scientific Party, 2003). At site 1232 (500 km south of the Reloca site), $\sim 47.5 \mathrm{~cm} / \mathrm{Kyr}$ were proposed as average sedimentation rate for the last $780 \mathrm{Kyr}$. (b) For the trench, but from a perched position on top of an isolated, $200 \mathrm{~m}$ high seamount, a rate was determined for gravity core 50SL. 


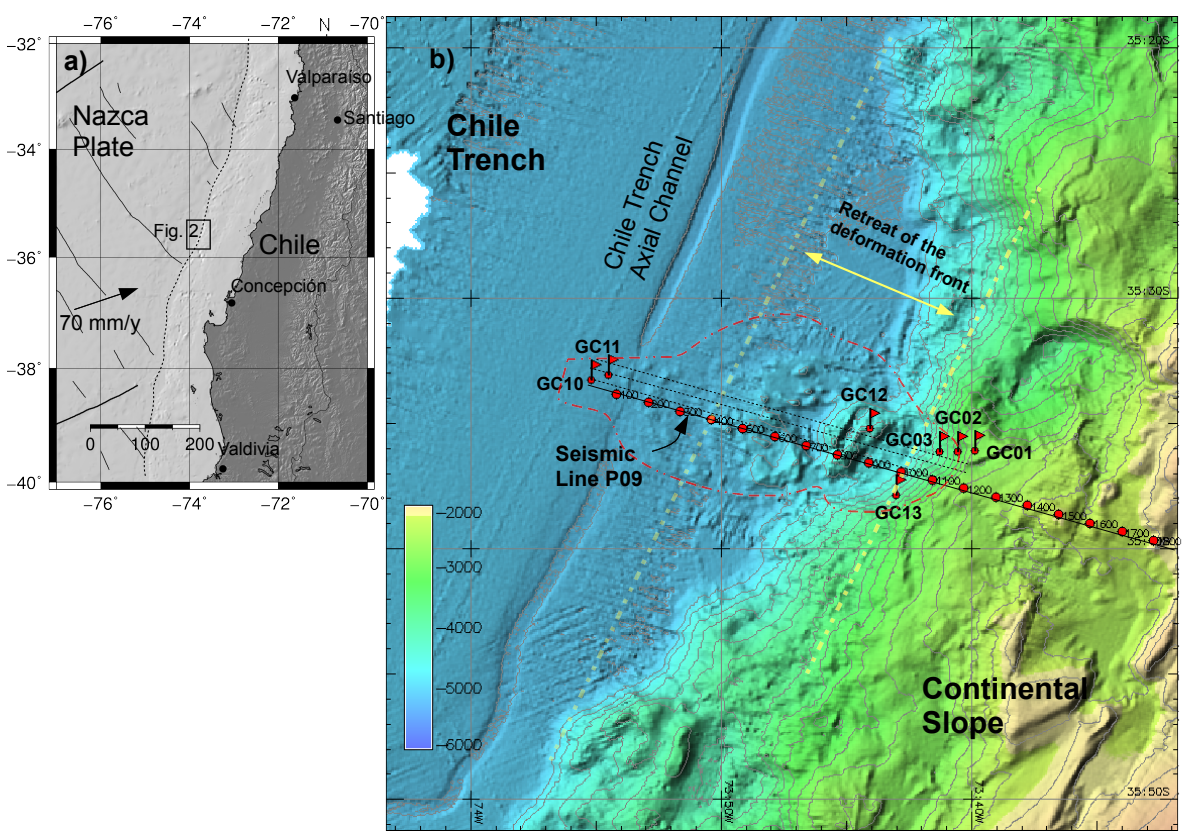

Fig. 1. Map view of Reloca Slide with positions of gravity cores (GC) and seismic line P09 of RRS JAMES COOK cruise JC23b. The red stippled line indicates the area affected by the slide, fine black stippled lines indicate positions of depth profiles used for Fig. 3.

This core was retrieved $310 \mathrm{~km}$ south of Reloca Slide and $8.5 \mathrm{~km}$ away from the deformation front and a mean sedimentation rate of about $12 \mathrm{~cm} / \mathrm{Kyr}$ for Holocene was proposed (Völker et al., 2008). (c) For the continental slope offshore Concepción (100 km south of Reloca Slide), rates were determined over the past $\sim 100$ years for two sites at 1294 and $2065 \mathrm{~m}$ water depth (Muñoz et al., 2004). The very high values of $0.18 \pm 0.02 \mathrm{~cm} / \mathrm{y}$ were explained by the vicinity of the BioBio Submarine Canyon.

\section{Description of the Reloca Slide}

\subsection{Morphology}

At $73^{\circ} 46^{\prime} \mathrm{W} 35^{\circ} 35^{\prime} \mathrm{S}$, a blocky mass of material lies at the foot of the continental rise and extends onto the $5100 \mathrm{~m}$ deep, flat floor of the sediment-filled Chile Trench (Fig. 1). We interpret this feature to be a slide body, the Reloca Slide, named for the Reloca River of the Talca Province in the Maule Region of Central Chile. The Reloca slide body is constructed of three major blocks (Fig. 2a, blocks 1-3) rising some $100 \mathrm{~m}$ and about 25 smaller blocks (Fig. 2a, blocks 4-28) rising some $10 \mathrm{~m}$ above a surrounding cone of scattered debris. The dimensions of the area directly affected by the slide are $16 \mathrm{~km} \mathrm{~N}-\mathrm{S}$ and $18 \mathrm{~km} \mathrm{E-W}$. The major blocks (blocks 1-3) cover areas of $12.4,8.8$ and $15.2 \mathrm{~km}^{2}$, respectively.

The outlying debris field has a maximum run-out distance of $18 \mathrm{~km}$ from the lowermost slope. It crosses and partly buries the 50-60 m deep central axial channel of the Chile Trench (Fig. 2a). This debris field has the form of a flattopped fan that is elongated in E-W direction. It forms a distinct edge of roughly $60 \mathrm{~m}$ height difference at its northern limit, best seen as a slope gradient anomaly (Fig. 2b, arrow 2). We traced the seaward limit of a corresponding debrite deposit with the help of a sediment echo sounder to deposit to $73.92^{\circ} \mathrm{W}$ longitude (Figs. 1, 2a). The smaller blocks form clusters within the debris cone (Fig. 2a, b, arrow 1). A number of blocks seem to be aligned on the outer rim of the debris cone (blocks 15-25, Fig. 2a). At the distal most end of the slide debris, two block (blocks 24 and 25) of 10-20 m elevation and 0.37 resp. $0.24 \mathrm{~km}^{2}$ size lie west of the axial channel (Fig. 2a, b, arrow 2). The size and elevation of the blocks is given in Table 1. The transition between the slide debris and the regular trench fill sediment does not show up in backscatter images of the SIMRAD EM120 bathymetric echo sounder (Fig. 2c, box 5).

The largest two blocks (1 and 2) appear compact and angular with steep flanks facing seaward and landward (25-35 inclination, Fig. 2b). Block 1 lies directly at the foot of the lowermost continental slope. This block and the lowermost slope form a closed drainage basin of $4.5 \times 1.8 \mathrm{~km}$ extension $\left(8.3 \mathrm{~km}^{2}\right.$ area $)$ that has accumulated sediment. The flat-lying sediment fill shows low backscatter (Fig. 2c, arrow 6).

The lower continental slope facing Reloca Slide is steep $\left(20-30^{\circ}\right)$. It has an arcuate form with a defined headscarp edge and sidewalls and and is therefore interpreted to be the headscarp of the slump (Fig. 2a, b). This $2000 \mathrm{~m}$ high headscarp has an edge at about 2900-3000 m water depth, where 

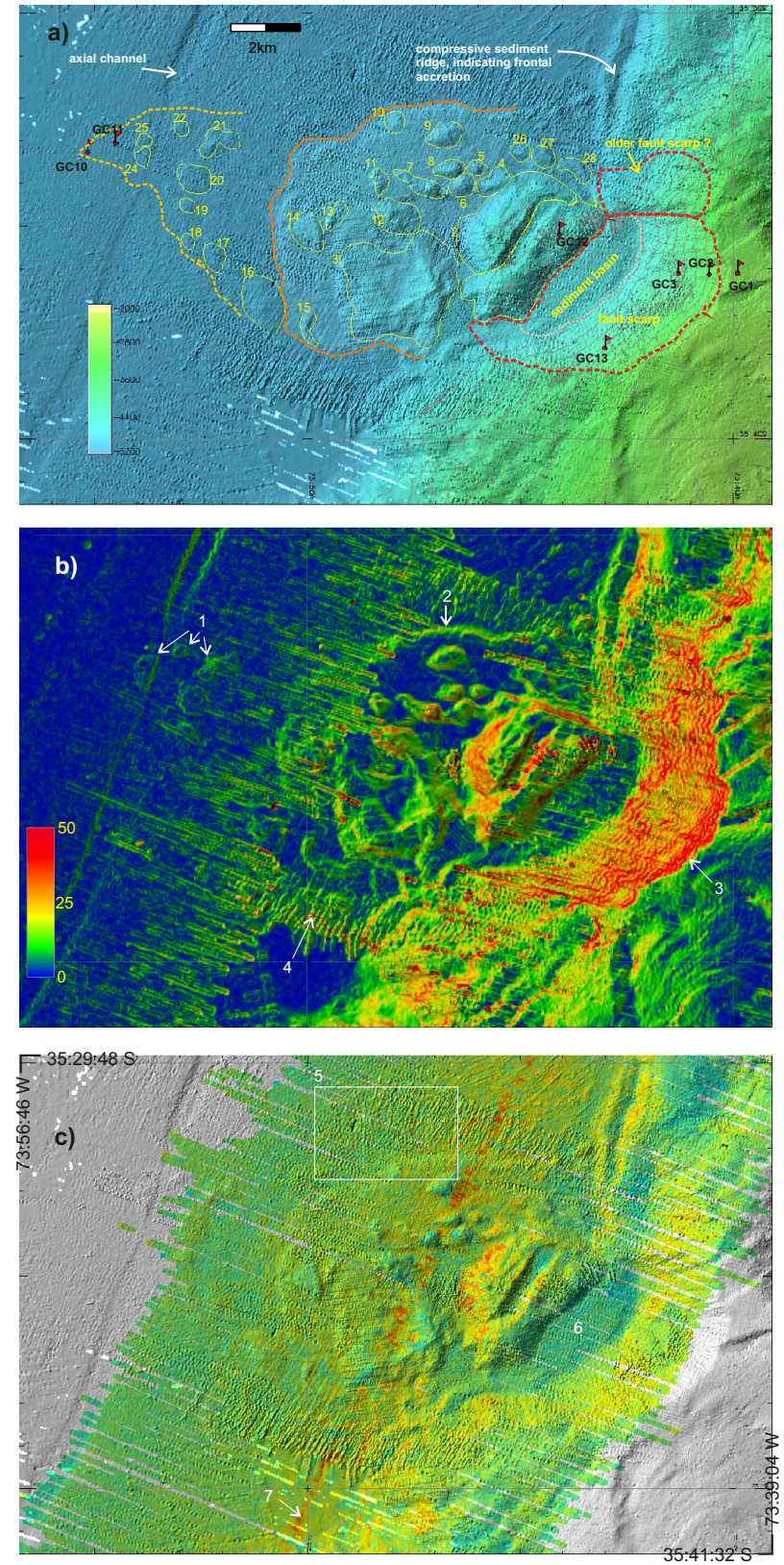

Fig. 2. Detailed map view of the Reloca Slide. (a) shaded bathymetry map superimposed with the outlines of 28 slide blocks and the outer rim of the of the debris fan. The main fault scarp, a possible older fault scarp and the sedimentary basin are highlighted by stippled lines. (b) Slope gradient map. The blocks transported furthest seaward and across the axial channel are indicated by arrow 1 . The northern rim of the debris fan is highlighted by arrow 2 . The prominent edge of the headscarp is indicated by arrow 3. Arrow 4 shows artificial roughness of the bathymetric grid caused by poor heave correction of a survey. (c) Backscatter data of a single survey superimposed on the bathymetry. Box 5 demonstrates no difference between trench sediments and slide deposits, maybe due to post-slide sediment cover. The sedimentary basin shows low backscatter (6).
Table 1. Dimensions and elevation of the blocks composing Reloca Slide.

\begin{tabular}{lrrrrr}
\hline $\begin{array}{l}\text { Block } \\
\#\end{array}$ & $\begin{array}{r}\text { Area } \\
{\left[\mathrm{km}^{2}\right]}\end{array}$ & $\begin{array}{r}\text { Summit } \\
\text { Elevation }[\mathrm{m}]\end{array}$ & $\begin{array}{r}\text { Block } \\
\#\end{array}$ & $\begin{array}{r}\text { Area } \\
{\left[\mathrm{km}^{2}\right]}\end{array}$ & $\begin{array}{r}\text { Summit } \\
\text { Elevation }[\mathrm{m}]\end{array}$ \\
\hline $\mathbf{1}$ & 12.4 & 4400 & $\mathbf{1 5}$ & 0.5 & 5025 \\
$\mathbf{2}$ & 8.9 & 4450 & $\mathbf{1 6}$ & 2.9 & 5010 \\
$\mathbf{3}$ & 15.2 & 4670 & $\mathbf{1 7}$ & 0.8 & 5035 \\
$\mathbf{4}$ & 1 & 4885 & $\mathbf{1 8}$ & 0.2 & 5030 \\
$\mathbf{5}$ & 0.4 & 4900 & $\mathbf{1 9}$ & 0.3 & 5035 \\
$\mathbf{6}$ & 0.7 & 4900 & $\mathbf{2 0}$ & 1.3 & 5030 \\
$\mathbf{7}$ & 1 & 4800 & $\mathbf{2 1}$ & 1.1 & 5025 \\
$\mathbf{8}$ & 0.7 & 4880 & $\mathbf{2 2}$ & 0.3 & 5025 \\
$\mathbf{9}$ & 1.1 & 4885 & $\mathbf{2 4}$ & 0.4 & 5040 \\
$\mathbf{1 0}$ & 0.6 & 4945 & $\mathbf{2 5}$ & 0.2 & 5040 \\
$\mathbf{1 1}$ & 0.5 & 4945 & $\mathbf{2 6}$ & 0.5 & 4920 \\
$\mathbf{1 2}$ & 1.9 & 4870 & $\mathbf{2 7}$ & 0.6 & 4910 \\
$\mathbf{1 3}$ & 0.6 & 4920 & $\mathbf{2 8}$ & 0.8 & 4930 \\
$\mathbf{1 4}$ & 1.5 & 4880 & & & \\
\hline
\end{tabular}

the slope gradient increases seawards from $5^{\circ}$ to $40^{\circ}$ over a short distance (Fig. 2b, arrow 3). Downslope of $3300 \mathrm{~m}$, the slope gradient decreases to about $25^{\circ}$, a value that is maintained until the floor of the sediment basin in the back of the largest slump block is met.

A profile that runs WNW-ESE in line with its extension across the slide clearly shows the morphological elements (Fig. 3): the headscarp with a pronounced edge, the sliding ramp of the failure plane, the main mass of the slide as large angular blocks and the runout. The dimensions are listed in Table 2a. According to the classifications of Prior and Coleman (1979), Mulder and Cochonat (1996) and Hampton et al. (1996), the term underwater slide refers to thin, translational, failures that travel long distances, while the term underwater slump refers to thick, rotational, failures that occur with minimal down-slope displacement. The division between the two is based on the ratio between the thickness $T$ and length $b$ of the mass wasting feature (T/b, Skempton Ratio, Mulder and Cochonat, 1996). With a Skempton Ratio of 0.04 to 0.16 (values of $T$ and $b$ in Table 1a), the feature falls into the category of slides.

It is notable, that from $20 \mathrm{~km}$ north to $15 \mathrm{~km}$ south of Reloca Slide (Between $35^{\circ} 20^{\prime} \mathrm{S}$ and $35^{\circ} 45^{\prime} \mathrm{S}$ ), the deformation front appears indented by about $10 \mathrm{~km}$ (Fig. 1).

\subsection{Volume estimation}

Approximations of the volume of the slide mass deposited in the trench and the missing material from at the headscarp were calculated with a Digital Elevation Model using the Generic Mapping Tools (GMT, Wessel and Smith, 1998) and GRASS GIS (Neteler and Mitsatova, 2004) programs. In order to derive volume estimations, we mapped the outline of the Reloca Slide, created an hypothetical pre-slide 
Table 2. a) Basic dimensions of Reloca Slide, b) terminal velocity, tsunami wavelength and tsunami wave amplitude after Watts et al. (2003).

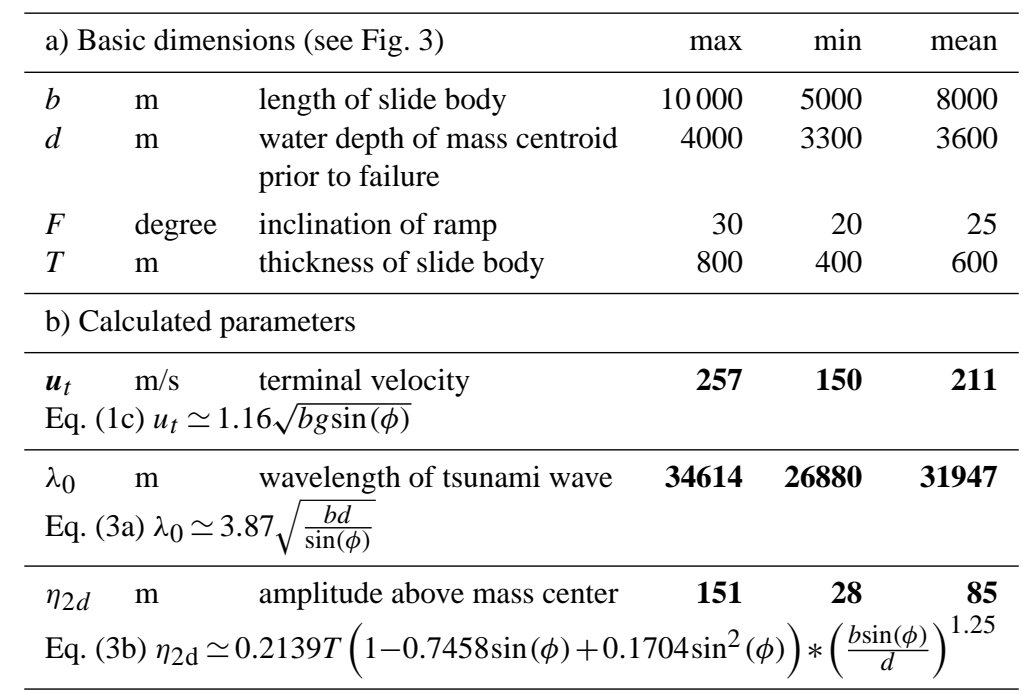

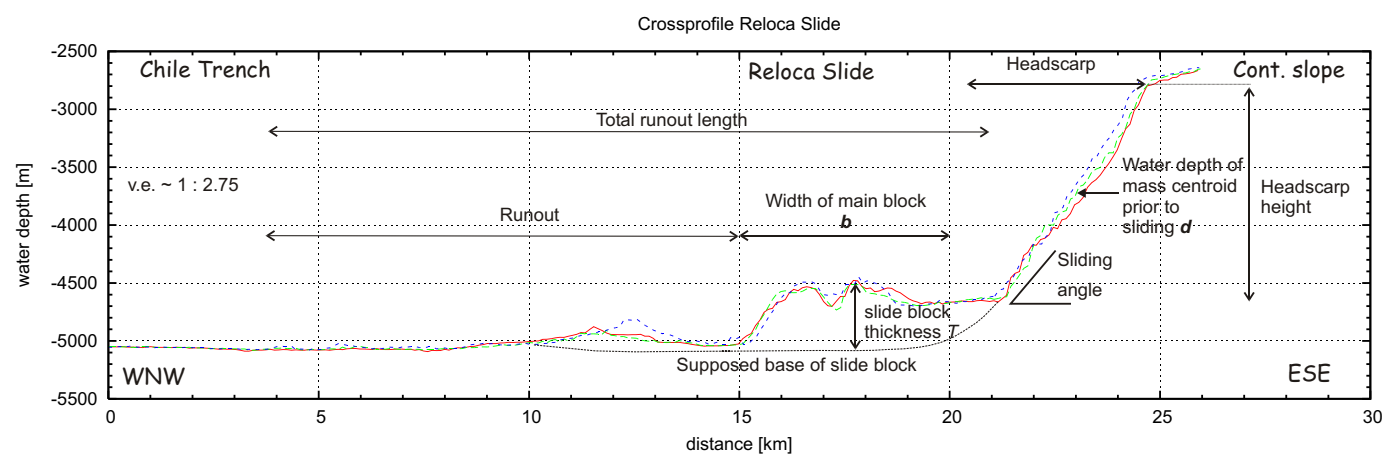

Fig. 3. Depth profile across Reloca Slide, showing major morphological elements and properties. The position of profiles is indicated in Fig. 1 as thin, dotted lines.

bathymetry of the Chile Trench and slope and calculated the volumes between the two surfaces within the slide outline.

The creation of the pre-slide bathymetry of the trench was accomplished by removing the swath bathymetry data from within the outline of the slide area and replacing them by extrapolated elevation values. This was relatively easy for the slide mass as it rises from the flat trench floor of 5060$5070 \mathrm{~m}$ water depth. Restoration of the slope was accomplished by copying the morphology of slope regions adjacent to the slide scar to the headscarp area (method described in Völker, 2009). Both calculations were done repeatedly and with different sets of interpolation parameters, resulting in six versions of the pre-slide bathymetry and, accordingly, value ranges for the volumes from 14.3 to $17.3 \mathrm{~km}^{3}$ (mean of all models: $15.5 \mathrm{~km}^{3}$ ). Our preferred version of a restored slide headscarp and trench is shown in Fig. 4.

The calculated volumes of the slide mass only account for the fraction of the slide body that rises above the trench

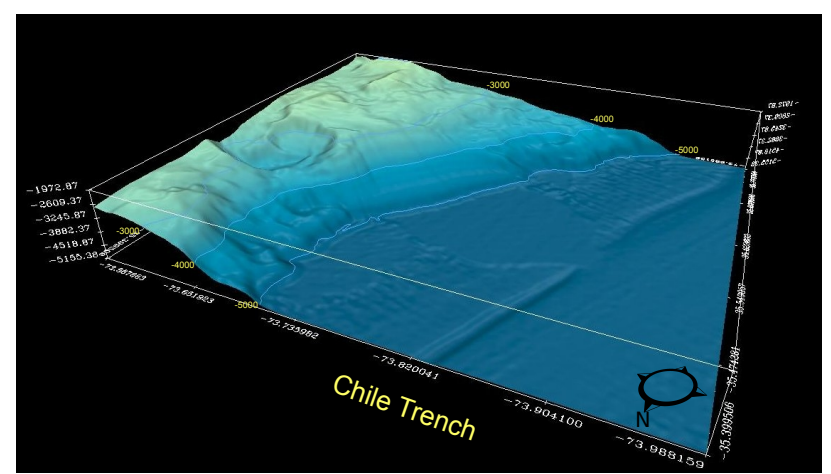

Fig. 4. Perpective view of the restored hypothetical "pre-slump" morphology that was used to calculate missing volumes at the slope and displaced masses in the trench. 


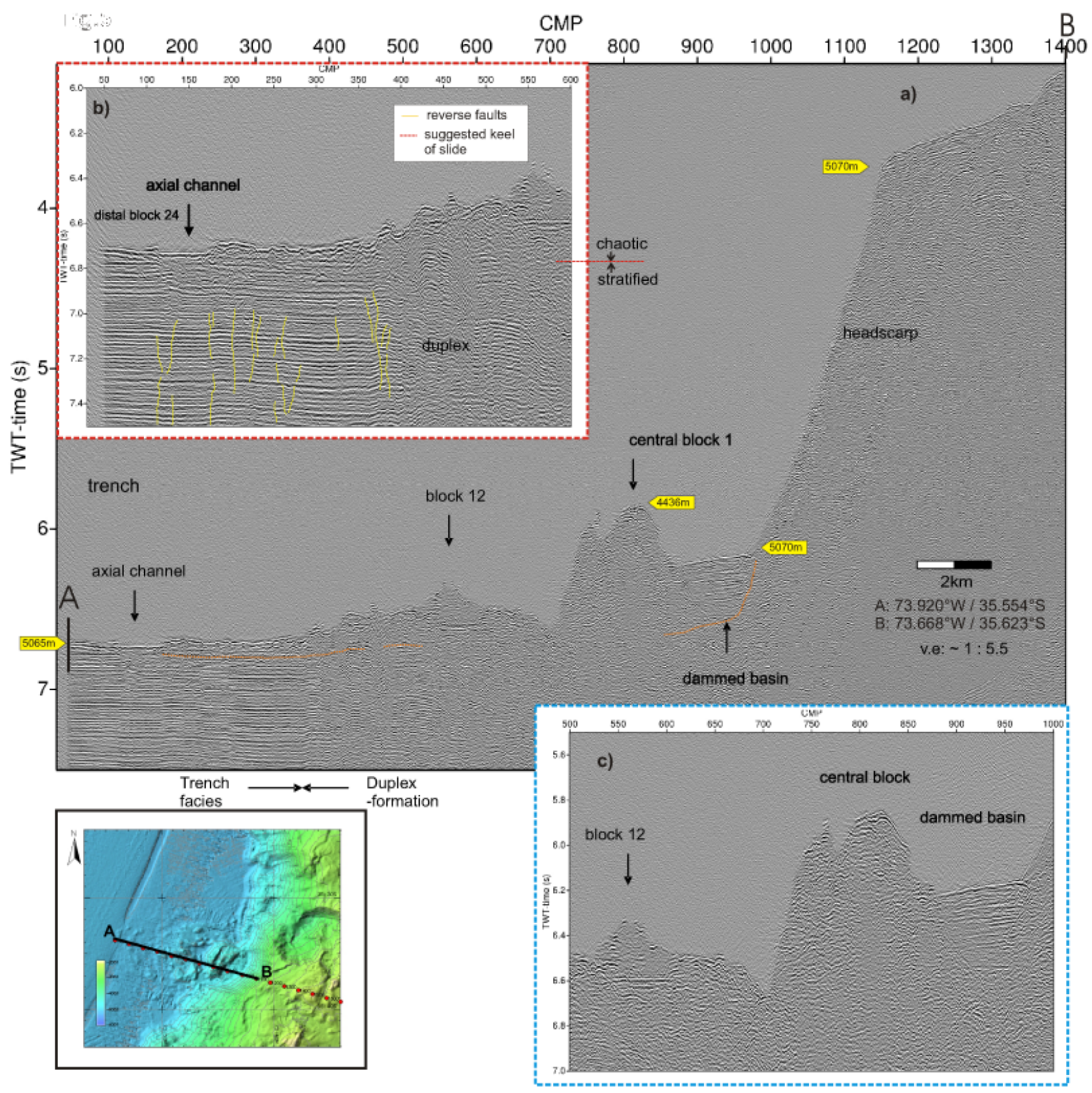

Fig. 5. Seismic profile P09 of RRS JAMES COOK expedition JC23b across Reloca Slide. Insert (b) shows the transition of undisturbed, parallel sediments of the trench facies to increasing compressional deformation when approaching the continental margin, as well as the transition of chaotic to well stratified strata that depicts the lower slide boundary. Insert (c) highlights the enigmatic sediment fill of the small basin in the back of slide block 1 .

floor. A fraction is hidden, as the larger blocks are partly buried in the upper beds of the trench fill. A reflection seismic data profile, recorded on the RRS JAMES COOK cruise $\mathrm{JC} 23 \mathrm{~b}$ with a 4-channel mini-streamer of $65 \mathrm{~m}$ active length and shot with a 250 cubic inch GI gun (Flueh and Bialas, 2008) runs across Reloca Slide (Fig. 1, red line). The lower, buried boundary of the slide is depicted in parts of this profile. Landward from the axial channel to the distal slide
(Common Midpoints or CMP, 170-400) it is visible as downward transition from a chaotic reflection pattern to a more uniformly stratified unit (Fig. 5b). Further landward (CMP 400-500), this transition gets obscured by compressional deformation features (duplexes) of the trench sediment. From CMP 500-550 (Fig. 5c), again the well stratified strata of below the slide are seen at a TWT of 0.2 to 0.22 from the sea floor which has a depth of $4910 \mathrm{~m}$ (CMP 500), respec- 
Table 3. Calculated volumes of the slide scar as well as the slide mass and it's major components. The volumes of the slide scar represent a mean of six model runs with the same elevation input values but different interpolation parameters. As the water depth of the trench floor ranges between 5050 and $5070 \mathrm{~m}$, we conducted three calculations and propose a mean.

\begin{tabular}{|c|c|c|c|c|c|c|}
\hline Slide element & Descrip & ion of model run & $\begin{array}{r}\text { Volume }\left[\mathrm{km}^{3}\right] \\
\text { (mean of } 6 \\
\text { models) }\end{array}$ & $\begin{array}{r}\text { Standard } \\
\text { deviation } \\
{\left[\mathrm{km}^{3}\right]}\end{array}$ & Mean $\left[\mathrm{km}^{3}\right]$ & $\begin{array}{r}\text { Mean, } \\
\text { corrected for } \\
\text { keel depth }\left[\mathrm{km}^{3}\right]\end{array}$ \\
\hline 1) Slide scar & $\begin{array}{l}\text { Rec. } 1 \\
\text { Rec. } 2\end{array}$ & $\begin{array}{l}\text { conservative } \\
\text { generous }\end{array}$ & $\begin{array}{l}14.3 \\
17.3\end{array}$ & $\begin{array}{l}0.27 \\
0.17\end{array}$ & 15.5 & - \\
\hline 2) Slide mass & $\begin{array}{l}\text { Rec. } 1 \\
\text { Rec. } 2 \\
\text { Rec. } 3\end{array}$ & $\begin{array}{l}\text { Base }-5050 \mathrm{~m} \\
\text { Base }-5060 \mathrm{~m} \\
\text { Base }-5070 \mathrm{~m}\end{array}$ & $\begin{array}{r}16 \\
17.1 \\
18.4\end{array}$ & $\begin{array}{l}- \\
- \\
-\end{array}$ & 17.1 & 22.3 \\
\hline 2a) Block 1 & $\begin{array}{l}\text { Rec. } 1 \\
\text { Rec. } 2 \\
\text { Rec. } 3\end{array}$ & $\begin{array}{l}\text { Base }-5050 \mathrm{~m} \\
\text { Base }-5060 \mathrm{~m} \\
\text { Base }-5070 \mathrm{~m}\end{array}$ & $\begin{array}{l}5.6 \\
5.7 \\
5.9\end{array}$ & $\begin{array}{l}- \\
- \\
-\end{array}$ & 5.7 & 8 \\
\hline 2b) Block2 & $\begin{array}{l}\text { Rec. } 1 \\
\text { Rec. } 2 \\
\text { Rec. } 3\end{array}$ & $\begin{array}{l}\text { Base }-5050 \mathrm{~m} \\
\text { Base }-5060 \mathrm{~m} \\
\text { Base }-5070 \mathrm{~m}\end{array}$ & $\begin{array}{l}2.7 \\
2.8 \\
2.9\end{array}$ & - & 2.8 & 3.9 \\
\hline 2c) Block3 & $\begin{array}{l}\text { Rec. } 1 \\
\text { Rec. } 2 \\
\text { Rec. } 3\end{array}$ & $\begin{array}{l}\text { Base }-5050 \mathrm{~m} \\
\text { Base }-5060 \mathrm{~m} \\
\text { Base }-5070 \mathrm{~m}\end{array}$ & $\begin{array}{l}2.6 \\
2.8 \\
2.9\end{array}$ & $\begin{array}{l}- \\
- \\
-\end{array}$ & 2.8 & 3.9 \\
\hline
\end{tabular}

tively 4930 (CMP 550). With a sediment sound velocity of $2000 \mathrm{~m}$ per second (Contreras-Reyes, 2008) this translates into a depth of $200-220 \mathrm{~m}$. The keel depth with respect to the mean trench floor depth of $5060 \mathrm{~m}$, is therefore $50-80 \mathrm{~m}$, the ratio between keel depth and elevation above the basis at $5060 \mathrm{~m}$ lie in the range of $0.4-0.5$ at this particular place. If this ratio between the volumes buried beneath respectively standing out from the basal plane of the trench were a general feature for the slide, one would have to apply a volume correction by a factor of 1.4 to 1.5 to the slide volume calculated from the parts rising from the trench abyssal plain. The configuration of the seismic device did, however, not allow to depict the lower boundary of the main block. The lower boundary of the sedimentary basin can be seen in Fig. 5c). We suggest a lower slide boundary by connecting the concave basis of the basin with the profile segments where the transition is seen (Fig. 5a). Following this suggestion, we propose a correction factor of 1.4 for the buried parts of the Reloca Slide. The resulting volumes for the headscarp, the slide mass and the major blocks are listed in Table 3. According to our calculations, the slide comprises of a total volume of $24 \mathrm{~km}^{3}, 66 \%$ of which is represented by the three largest, compact blocks.

\subsection{Sediment sampling}

Sediment gravity cores were collected during RRS JAMES COOK cruise JC23b (Flueh and Bialas, 2008). The coring plan was laid out to sample an undisturbed reference core upslope of the headscarp, several samples from the headscarp, the top of the most elevated slide block 1 and the distal most parts of the slide (Table 4, Figs. 1, 2a). The two coring sites from the distal part of the landslide were chosen on basis of analog sediment echo sounder data that showed a $1-3 \mathrm{~m}$ thick, well-layered top part (post-slump sediments) resting on an acoustically transparent, wedge-shaped sediment body (debrite, slumped material). The goal was to sample both acoustic units in order to provide material appropriate for dating the event. This was achieved at gravity core station GC11 (Fig. 6, Table 4). From the sea floor to $131.5 \mathrm{~cm}$ depth below sea floor (bsf.), the sediment column consists of homogeneous, brown silty clay to clay, intercalated by few thin volcanic ash layers and a $7.5 \mathrm{~cm}$ thick, internally layered bed of sand-sized dark gray volcanic ash at the base. Below this tephra layer, from 139 to $303 \mathrm{~cm}$ bsf., there is a lithological unit that consists of lenses of heterogeneous material. There is no layering visible, instead, sediment clasts of up to $10 \mathrm{~cm}$ size in diameter are stacked chaotically. The chaotic structure of this unit is well visible as the clasts show different colors, thus producing a patchy appearance with a dominance of dark gray and light gray patches (Fig. 6). The clasts are slightly rounded and internally uniform. They consist of finesand sized material with the exception of some lenses of clay stones. The unit ends at $303 \mathrm{~cm}$ bsf., from here to the bottom of the core at $516 \mathrm{~cm}$ bsf, again homogeneous silty clay, intercalated by a number of thin volcanic ash layers dominate, with the exception of a bed $(470.5-495 \mathrm{~cm})$ that shows wavy layering and color changes, similar but less pronounced than the distinct bed from 139 to $303 \mathrm{~cm}$ bsf. 
Table 4. Gravity core sites of RRS JAMES COOK cruise JC23b at the Reloca Slide site.

\begin{tabular}{|c|c|c|c|c|c|c|}
\hline Name & $\begin{array}{r}\text { Longitude } \\
\text { [degree] }\end{array}$ & $\begin{array}{l}\text { Latitude } \\
\text { [degree] }\end{array}$ & $\begin{array}{r}\text { Water Depth } \\
{[\mathrm{m}]}\end{array}$ & $\begin{array}{r}\text { Length } \\
{[\mathrm{cm}]}\end{array}$ & Situation & General lithology \\
\hline JC23b-GC01 & -73.6648 & -35.6018 & 2889 & 672 & $\begin{array}{l}\text { Reference core } \\
\text { up-slope of } \\
\text { fault headscarp }\end{array}$ & $\begin{array}{l}\text { Silty homogeneous } \\
\text { clay, intercalated by } \\
\text { sand-sized volcanic ash } \\
\text { layers }\end{array}$ \\
\hline JC23b-GC02 & -73.6760 & -35.6024 & 3398 & 7 & $\begin{array}{l}\text { Upper } \\
\text { headscarp }\end{array}$ & $\begin{array}{l}\text { Silty material,very dry } \\
\text { and hard. Thin (1- } \\
2 \mathrm{~cm}) \text { layer of mud on } \\
\text { top }\end{array}$ \\
\hline $\mathrm{JC} 23 \mathrm{~b}-\mathrm{GC} 03$ & -73.6881 & -35.6020 & 5054 & 30 & $\begin{array}{l}\text { Central } \\
\text { headscarp }\end{array}$ & $\begin{array}{l}\text { Very hard, gray and al- } \\
\text { most dry clay. Had } \\
\text { to be removed from the } \\
\text { core tip with hammer } \\
\text { and chisel. }\end{array}$ \\
\hline JC23b-GC10 & -73.9200 & -35.5500 & 5054 & 30 & $\begin{array}{l}\text { Distal } \\
\text { (western- } \\
\text { most) end } \\
\text { of slump, W of } \\
\text { axial channel }\end{array}$ & $\begin{array}{l}\text { Homogeneous silty } \\
\text { clay }\end{array}$ \\
\hline JC23b-GC11 & -73.9100 & -35.5500 & 5056 & 516 & $\begin{array}{l}\text { Distal end of } \\
\text { slump, west of } \\
\text { the axial chan- } \\
\text { nel }\end{array}$ & $\begin{array}{l}\text { Homogeneous silty } \\
\text { clay with ash layers, } \\
\text { disrupted by a unit } \\
\text { of chaotically stacked } \\
\text { clasts of various origin } \\
\text { (debrite, see Fig. 6) }\end{array}$ \\
\hline $\mathrm{JC} 23 \mathrm{~b}-\mathrm{GC} 12$ & -73.7300 & -35.5900 & 4473 & 203 & $\begin{array}{l}\text { Summit of east- } \\
\text { ernmost slump } \\
\text { block }\end{array}$ & $\begin{array}{l}\text { Silty homogeneous } \\
\text { clay, intercalated by a } \\
\text { thick bed of clay stone } \\
\text { and volcanic ash clasts. } \\
\text { Bottom layer coarse } \\
\text { sandy layer of volcanic } \\
\text { ash }\end{array}$ \\
\hline JC23b-GC13 & -73.7200 & -35.6300 & 3920 & 15 & $\begin{array}{l}\text { Central head- } \\
\text { scarp }\end{array}$ & Hard, dry clay \\
\hline
\end{tabular}

The summit of the main slide block was sampled at gravity core station GC12, but the corer hit a thick and very coarse (sand-gravel) layer of volcanic debris at $200 \mathrm{~cm}$ depth bsf. and was bent. From $30 \mathrm{~cm}$ bsf. to this layer, the core contained dark brown homogeneous clay with the exception of a $9 \mathrm{~cm}$ thick bed of reworked rounded clay galls and tephra at 80-89 cm bsf.

The headscarp and sliding plane resisted corer penetration. The core catcher was filled by about $20 \mathrm{~cm}$ of extremely stiff, almost dry clay (GC02, GC03 and GC13). At GC03, the material had to be removed from the cutter with hammer and chisel. Obviously, the combination of steep slope $\left(20-25^{\circ}\right)$ and very compacted material made it impossible to sink the corer in.

\section{Discussion}

\subsection{The Reloca Slide event}

The slide shows a bimodal morphology with three large, angular main blocks close to the headscarp and a debris cone including scattered smaller blocks. This morphology lets us suggest that the slide was a two-stage event. In the first stage, a 400-500 m thick rock unit detached from the failure plane and slid down the slide scar with little internal deformation but the separation of what now are the three main blocks and possibly a slight rotation. The three blocks comprise the major volume $(66 \%)$ of the failed mass, respectively almost the total of the volume hypothetically missing at the slope. The 


\section{JC23b GC11}

\section{Segment $114-214.5 \mathrm{~cm}$}

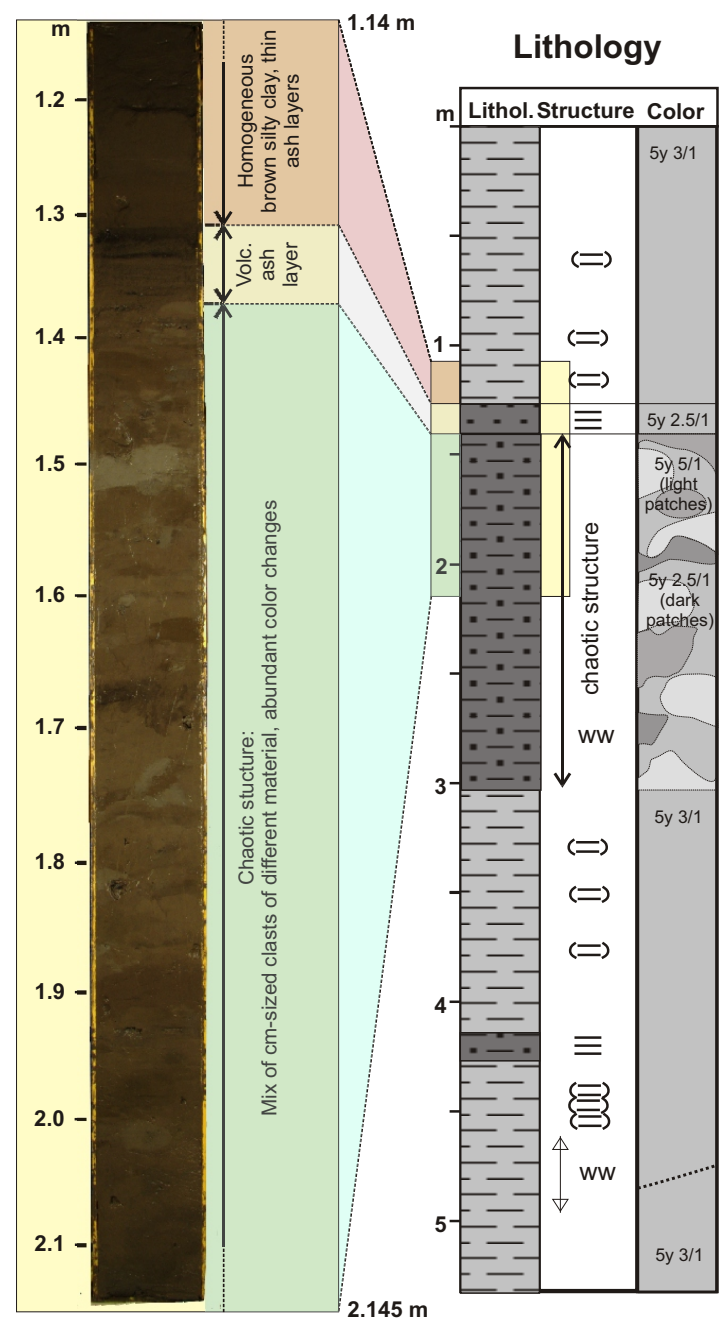

$35^{\circ} 33.05^{\prime} \mathrm{S} 73^{\circ} 54.51^{\prime} \mathrm{W}$

Water Depth: $5056 \mathrm{~m}$

Core Length: $516 \mathrm{~cm}$

Distal toe of Reloca Slide

\section{Remarks}

0-70 cm: Brown silty clay to clay, homogeneous $70 \mathrm{~cm}$ : ash clast, light gray, $5 \mathrm{~mm}$ diameter 75-76, 93-99, 103-105 cm: Layer of more compacted, possibly claystone clasts, up to 5 $\mathrm{mm}$ diameter

$108-109 \mathrm{~cm}$ : large clast of compacted, dark gray material

$121-122 \mathrm{~cm}$ : fine-sandy ash layer

$122-131.5 \mathrm{~cm}$ : homogeneous silty clay

$131.5-139 \mathrm{~cm}$ : coarse, sand-sized volcanic ash layer., internally layered but not clearly graded $139-303 \mathrm{~cm}$ chaotic structures: large $(10 \mathrm{~cm})$ rounded clasts and lenses of silt-fine sand grain size ranging in colour from dark gray to light gray are mixed into a lithological unit: $142-144 \mathrm{~cm}$ : dark patch; 150-152 cm: light gray lens; $159 \mathrm{~cm}$ : dark gray lens; $161 \mathrm{~cm}$ : light gray lens; 163-165 $\mathrm{cm}$ : light gray lens next to dark lens; $170 \mathrm{~cm}$ : claystone clast $5 \mathrm{~mm}$ diameter; 174-176: light patch

$182 \mathrm{~cm}$ : lens of reworked claystone material 193-194: lens of dark gray fine sand $214-241 \mathrm{~cm}$ : silty clay, abundant color changes as layers and mottles

$241-244 \mathrm{~cm}$ : dark fine sand (ash) layer

244-255 cm: silty clay, abundant color changes $255-260,271-277,300-303 \mathrm{~cm}$ : dark fine sand (ash) layers

$303-415 \mathrm{~cm}$ : silty clay, homogeneous

$327.5-329,351-354,375-376 \mathrm{~cm}$ : dark gray ash layers

$340,354,357,378 \mathrm{~cm}$ : light gray ash clasts $415.5-423.5 \mathrm{~cm}$ : dark gray fine sand layer (ash), distinct lower boundary

$443.5,446.5,452,466-468 \mathrm{~cm}$ : thin, dark gray layers in homogeneous gray silty clay matrix

$470.5-495 \mathrm{~cm}$ : wavy layering, lenses of different

colors defined by inclined lithological

boundaries, slightly chaotic.

$497-516 \mathrm{~cm}$ : homogeneous silty clay

$513.5 \mathrm{~cm}$ : thin, dark gray layer in homogeneous gray silty clay matrix

\section{Legend}

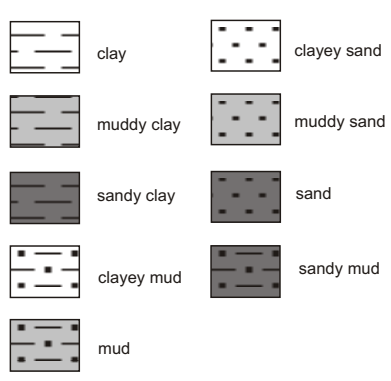

Structures

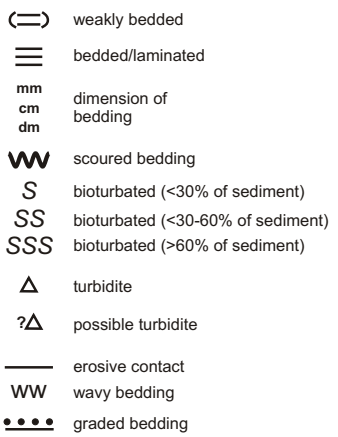
Fossils
$O$ shells
$\varnothing$ shell fragments
$\checkmark$ megafossils
cc carbonate concretion
disturbed sediment

Fig. 6. Lithology of gravity core GC11, retrieved of RRS JAMES COOK expedition JC23b from the distal end of Reloca Slide. The inserted photo highlights the transition from homogeneous, silty clay and a volcanic ash bed of the uppermost $139 \mathrm{~cm}$ of the core (post-emplacement sediments) to a thick bed of chaotically stacked sediment clasts (debrite deposit), most probably genetically related to Reloca Slide. The debrite is well visible because of its patchy appearance.

fact that they have not moved far from the headscarp may be due to the morphology of the ramp (Fig. 3), which is relatively steep and straight and ends without major transition at the flat trench floor. The motion must have been a rather steep and abruptly stopped drop instead of a continuous slide which would expected along a concave gliding plane with a gentle transition to the abyssal plain.

The debris cone formed in a subsequent stage as product of a debris flow that probably incorporated trench sediment material as the total calculated volume of the slide mass exceeds the calculated failed slope volume. It was thick and dense enough to support the scattered smaller blocks and transport them $18 \mathrm{~km}$ further westward and even across the axial channel. The E-W elongated morphology of the debris cone, its northern limit forming a $60 \mathrm{~m}$ step of the sea floor (Fig. 2b, arrow 2), the radial alignment of blocks along the rim of the debrite and its crossing of the axial channel witness a plastic behavior of the debrite. Also, they show that the motion of the debris flow came to a sudden still stand, once a certain threshold of kinetic energy was reached. It might be that during failure the slide mass separated into a more rigid lower part that broke into the three main and a number of smaller blocks in a brittle fashion, while a less consolidated part of the slope sediment developed into a debris flow that incorporated trench sediment and carried the smaller blocks further outward. The filling of the basin in the back of the largest slide block could be a third stage of the event. 


\subsection{Age of the event}

At present, we have only indirect information about the dating of the event:

1. The slide clearly postdates the incision of the central axial channel of the Chile Trench (Fig. 2a), as its distal most toe partly buries the channel. The channel is believed to have been either actively being carved or built about 10-12000 years ago when sediment input from the slope canyons was nourished by glaciated coastal drainages (Völker et al., 2006).

2. We suppose that the conspicuous bed in GC11 (139 to $303 \mathrm{~cm}$ bsf., Fig. 6) is a debris flow deposit that represents the distal most end of Reloca Slide, and that both the volcanic ash bed and the silty mud on top are post- emplacement sediments. If the trench sedimentation rate of about $47 \mathrm{~cm} / \mathrm{Kyr}$ that was calculated for site 1232 of ODP leg 202 (Shipboard scientific party, 2003) is representative, this converts into an age of $\sim 3 \mathrm{Kyr}$. GC12 probably was too short to penetrate the post emplacement sediment cover.

3. The sedimentary fill of the basin that formed between the slide block and the fault scarp is filled by a sequence of seismically stratified sediments. In our seismic reflection profile, this sequence has a maximum thickness of $0.4 \mathrm{~s}$ TWT (Fig. 5c). Assuming a seismic velocity of $1.8-2.0 \mathrm{~km} / \mathrm{s}$ (E. Contreras-Reyes, personal communication, 2008), this is equivalent to about $100 \mathrm{~m}$ of sediment. This is a very disconcerting finding, as it seems to contradict the assumption of a recent $(<12 \mathrm{Kyr})$ event. Taking into account the age ranges proposed beforehand, a local sedimentation rate of $10-30 \mathrm{~m} / \mathrm{Kyr}$ were necessary to build up this sequence. One way of resolving the direct contradiction is to propose a slow and nondestructive emplacement of a thick sediment sequence from the upper headscarp, coeval with or in the wake of the Reloca Slide event. We are not aware of any report of a similar process, though. Also, no sediment core was taken in the basin.

Efforts are underway to accurately date the postemplacement sediment cover by a combination of tephra-chronology of the ash bed directly overlying the distal Reloca Slide debrite and AMS ${ }^{14} \mathrm{C}$ dating. Also, we try to analyze the clasts composing the debris flow bed in GC11 for provenance and water depth of initial deposition.

\subsection{Possible Triggering of the Reloca Slide}

The high seismicity of the area could provide a trigger for mobilization of sediment deposited on the open slope or in slope basins. Whether or not this can result in large slope failures and generation of seismo-turbidites mainly depends

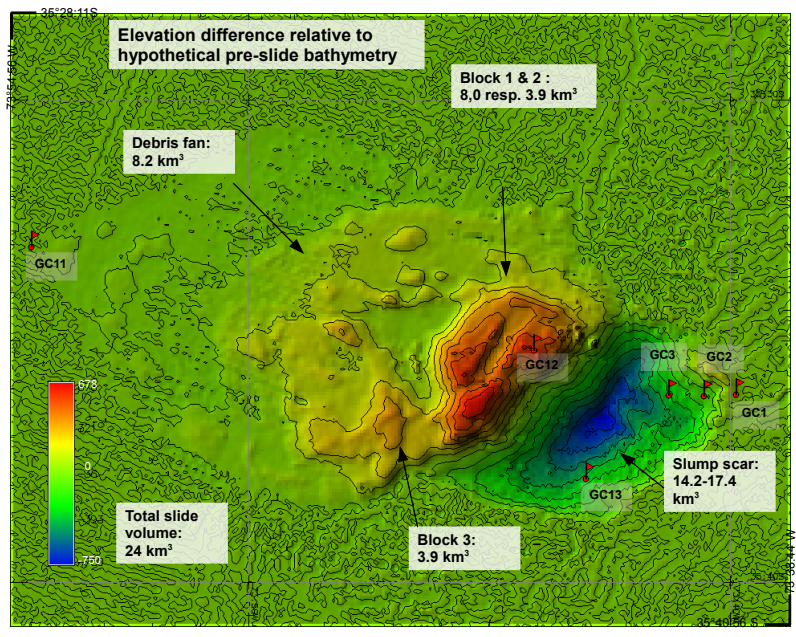

Fig. 7. Elevation difference between present day bathymetry of Reloca Slide and pre-slide bathymetry. The differential elevation shows, where most material was removed respectively deposited. The main blocks represent $2 / 3$ of the total slide volume, 1/3 was spread in the form of a debris fan. According to the model, sediments at coring locations GC2-3 and GC13 were subject to overburden pressure of a rock column of 150-350 m height. At the center of the headscarp, $\sim 700 \mathrm{~m}$ of rock were removed.

on the local sedimentation rates. Where sedimentation rate is low, regional high seismicity would perhaps rather limit the potential for voluminous slumping events as a seismic cycle of several hundred years as is documented for southern central Chile (Cisternas et al., 2005) would not provide sufficient time to store enough material (Blumberg, 2008; Völker et al., 2008). Even with the high sedimentation rates reported by Muñoz et al. (2004), the seismic cycle would allow for the buildup of a sediment blanket of only $20-40 \mathrm{~cm}$ in the interval between major earthquakes.

In the case of Reloca Slide however, the steep headscarp, the thickness and the blocky appearance of the main slide blocks rather suggest that slope failure occurred in the frontal prism material or even affected continental base rock. The mentioned indentation of the deformation front in the vicinity of the Reloca Slide area (Fig. 1) could be the result of a retreat of the lower slope due to mass removal processes preceding the Reloca Slide event. In this case it is possible that Reloca Slide affected not only frontally accreted material of the last few million years but cut through Paleozoic continental basement. The small amount of material that was retrieved from the slide scar at coring sites GC02, GC03 and GC13 (Table 2) consisted of compacted clay material, which rather points to frontally accreted material. We intend to study the Illite cristallinity (Kisch, 1991) of these sediments in order to get a grip on the degree of metamorphism and the related overburden pressure they were subject to. According to our reconstruction of the pre-slide bathymetry, the retrieved material has been buried by $150 \mathrm{~m}$ (GC02), respectively $350 \mathrm{~m}$ (GC03 and GC13) rock (Fig. 7). 
If the Reloca Slide involved compacted material of the accretionary wedge or even the Permo-Triassic backstop, it is likely that the slide scar evolved on a pre-existing fault surface. Deep-reaching normal faults that crosscut the lower and middle slope are noted in seismic reflection data of Rodrigo et al., 2009 (profile SO161-43). Such deep-reaching faults may have evolved as splay faults in a compressive regime such as at the convergent margin offshore Colombia (Collot et al., 2008).

Another option has been pointed out by Röser (2007). He shows, that sediments of the Chile Trench under certain pressures are prone to frictional behavior characterized by velocity weakening. This behavior could imply a threshold level for vertical loading under which gliding planes develop. This option will be investigated with geo-mechanical experiments on the failure scarp material.

\subsection{Implications for the tsunami hazard}

For the purpose of tsunami run-up estimates, Watts et al. (2003) model an underwater slide as a rigid body of simplified geometry moving along a straight incline with center of mass motion parallel to the incline and subject to external forces from added mass, gravity, and dissipation. Assuming a specific density $\gamma=1.85$, a negligible Coulomb friction coefficient $(C n=0)$, an added mass coefficient $(C m=1)$, and a drag coefficient $(C d=1)$. They come up with a set of simple equations for the description of the underwater slide motion, the tsunami amplitude and wavelength above the middle of the initial slide position, using the geometrical parameters $d$ (water depth of mass centroid prior to sliding), $b$ (length of slide body), $T$ (thickness of slide body) and $\theta$ (inclination of ramp) as input parameters (see Fig. 3). The relations are largely empirical and are used to perform coastal runup models. We omit this ultimate step for future modeling and present values for the terminal velocity of the slide $\boldsymbol{u}_{t}$, the tsunami amplitude $\lambda_{0}$ and tsunami wavelength $\eta_{2 d}$ using Eqs. (1c), (3a) and (3b) of Watts et al. (2003).

The results of the tsunami wave calculation for maximum, minimum and mean value input parameters are shown in Table $2 \mathrm{~b}$. We consider the calculated values for $\boldsymbol{u}_{t}, \lambda_{0}$ and $\eta_{2 d}$ as upper limits, as the condition of a Coulomb friction coefficient close to 0 is met only when the slide is completely decoupled. Nonetheless, the initial tsunami wave amplitude in the range of $30 \mathrm{~m}$ (the minimum value according to Watts et al., 2003) would mean a serious threat if the distance to the coast of $\sim 100 \mathrm{~km}$ is considered. The Sissano (Papua-New Guinea) tsunami that took the lives of 2000 people in 1998 was caused by a block slump of smaller size $\left(5-10 \mathrm{~km}^{3}\right)$ (Synolakis et al., 2002; Tappin et al., 2001).

An estimation of the size and run up of a tsunami potentially caused by the Reloca Slide requires more complex numerical modeling, which is a future goal. It is interesting, however, that the Reloca Slide area is not a unique in its steepness. There exist regions of similar or even steeper lower slope gradient between $33^{\circ} \mathrm{S}$ and $36^{\circ} \mathrm{S}$, around $38^{\circ} \mathrm{S}$, and from $39^{\circ} \mathrm{S}$ to $42^{\circ} \mathrm{S}$. In contrast to the Reloca Site, there are no slide deposits observable in the trench at these places. This could imply that these steep slopes are not the products of submarine mass wasting events but of tectonic oversteepening and that they could be prone to future mass wasting.

\section{Conclusions}

Reloca Slide is the largest described slide along the Chilean continental margin between 32 and $46^{\circ} \mathrm{S}$. It is a large volumetric mass $\left(\sim 24 \mathrm{~km}^{3}\right)$ of displaced continental slope material that maintained much of it's cohesion during the slump and run out process from a steep and high headscarp. Both observations suggest a sudden displacement of the the slide body that traveled vertically downward $2000 \mathrm{~m}$ and developed into a debris flow that traveled horizontally $18 \mathrm{~km}$ across the trench floor. This implies a that a localized but dimensionally large and high tsunami could have been generated that is only counteracted by a large water depth of $\sim 4500 \mathrm{~m}$ of the source area. With respect to tsunami risk, it is concerning that the Reloca Slide is relatively young, most likely postdating the last glacial maximum, and that long stretches of the lowermost continental slope exhibit a similar steepness and appearance as that around the Reloca Slide. Next steps will be (1) the exact dating of the event, thereby (2) resolving the apparent contradiction between a thick sediment sequence in the sedimentary basin formed by the most prominent slide block and the supposed young age of the slide, (3) geotechnical tests on material retrieved from the slide scar and (4) provenance analysis of the debrite components.

Acknowledgements. This paper is contribution No. 182 of Sonderforschungsbereich 574 (Special Research Area) "Volatiles and Fluids in Subduction Zones", funded by the German Research Foundation. We are grateful to the shipboard party of RRS JAMES COOK Cruise JC23. We also express our gratitude towards the reviewers John R. Smith and David W. Scholl, whose comments were extremely helpful.

Edited by: B. Tilling

Reviewed by: D. Scholl and J. Smith

\section{References}

Angermann, D., Klotz, J., and Reigber, C.: Space-geodetic estimation of the Nazca-South America Euler vector, Earth Planet. Sci. Lett., 171(3), 329-334, 1999.

Bangs, N. L. and Cande. S. C.: Episodic development of a convergent margin inferred from structures and processes along the southern Chilean margin, Tectonics, 16, 489-503, 1997.

Blumberg, S., Lamy, F., Arz, H. W., Echtler, H. P., Wiedicke, M., Haug, G. H., and Oncken, O.: Turbiditic trench deposits at the South-Chilean active margin: A Pleistocene-Holocene record of 
climate and tectonics, Earth Planet. Sci. Lett., 268, 526-539, 2008.

Cisternas, M., Atwater, B. F., Torrejon, F., Sawai, Y., Machuca, G., Lagos, M., Eipert, A., Youlton, C., Salgado, I., Kamataki, T., Shishikura, M., Rajendran, C. P., Malik, J. K., Rizal, Y., and Husni, M.: Predecessors of the giant 1960 Chile earthquake, Nature, 437(7057), 404-407, 2005.

Collot, J.-Y., Agudelo, W., Ribodetti, A., and Marcaillou, B.: Origin of a crustal splay fault and its relation to the seismogenic zone and underplating at the erosional north Ecuadorsouth Colombia oceanic margin, J. Geophys. Res., 113, B12102, doi:10.1029/2008JB005691, 2008.

Contardo, X., Cembrano, J., Jensen, A., and Díaz-Naveas, J. L.: Tectono-sedimentary evolution of marine slope basins in the Chilean forearc $\left(33^{\circ} 30^{\prime}-36^{\circ} 50^{\prime} \mathrm{S}\right)$ : Insights into their link with the subduction process, Tectonophysics, 459(1-4), 206-218, 2008.

Contreras-Reyes, E., Grevemeyer, I., Flueh, E. R., and Reichert, C.: Upper lithospheric structure of the subduction zone offshore of southern Arauco peninsula, Chile, at $\sim 38^{\circ} \mathrm{S}$, J. Geophys. Res, 113, B07303, doi:10.1029/2007JB005569, 2008.

Diaz-Naveas, J.: Sediment Subduction and Accretion at the Chilean Convergent Margin between $35^{\circ} \mathrm{S}$ and $40^{\circ} \mathrm{S}$. PhD thesis, Christian-Albrechts University, Kiel, 1999.

Flueh, E. and Bialas, J.: RRS JAMES COOK Cruise Report JC23A \& B. IFM-GEOMAR Report, 20, 242 pp., online available at: http://www.ifm-geomar.de/index.php?id=publikationen, 2008.

Glodny, J., Echtler, H. P., Figueroa, O., Franz, G., Gräfe, K., Kemnitz, H., Kramer, W., Krawczyk, C., Lohrmann, J., Lucassen, F., Melnick, D., Rosenau, M., and Seifert, W.: Long-Term Geological Evolution and Mass-Flow Balance of the South-Central Andes, The Andes - Active Subduction Orogeny: Frontiers in Earth Sciences: Berlin Heidelberg, Springer, 401-428, 2006.

Grevemeyer, I., Diaz-Naveas, J. L., Ranero, C. R., Villinger, H. W., and Scientific Shipboard Party: Heat flow over the descending Nazca plate in central Chile, 32 degrees $S$ to 41 degrees $S$ : observations from ODP Leg 202 and the occurrence of natural gas hydrates, Earth Planet. Sci. Lett., 213(3-4), 285-298, 2003.

Grevemeyer, I., Kaul, N., and Diaz-Naveas, J. L.: Geothermal evidence for fluid flow through the gas hydrate stability field off Central Chile - transient flow related to large subduction zone earthquakes?, Geophys. J. Int., 166, 461-468, 2006.

Hagen, R. A., Vergara, H., and Naar, D. F.: Morphology of San Antonio submarine canyon on the Central Chile forearc, Mar. Geol., 129, 197-205, 1996.

Hampton, M. A., Lee, H. J., and Locat, J.: Submarine landslides, Rev. Geophys., 34, 33-59, 1996.

Hervé, F., Faundez, V., Calderón, M., Masonne, H.-J., and Willner, A. P.: Metamorphic and plutonic basement complexes, in: The Geology of Chile, edited by: Moreno, T. and Gibbons, W., London, Geological Society of London, 5-21, 2007.

Kisch, H. J.: Illite crystallinity: recommendations on sample preparation, x-ray diffraction settings, and interlaboratory samples, J. Metamorphic Geol., 9, 665-670, 1991.

Krawczyk, C. M., Mechie, J., Lüth, S., Tassarova, Z., Wigger, P., Stiller, M., Brasse, H., Echtler, H. P., Araneda, M., and Bataille, K.: Geophysical Signatures and Active Tectonics at the SouthCentral Chilean Margin, in: The Andes - Active Subduction Orogeny, Frontiers in Earth Sciences, Springer, Berlin Heidel- berg, 167-187, 2006.

Kukowski, N. and Oncken, O.: Subduction Erosion - the "Normal" Mode of Fore-Arc Material Transfer along the Chilean Margin?, in: The Andes - Active Subduction Orogeny, edited by: Oncken, O., Chong, G., Franz, G., Giese, P., Götze, H.-J., Ramos, V. A., Strecker, M. R., and Wigger, P., Frontiers in Earth Sciences, Springer, Berlin Heidelberg, 213-223, 2006.

Lamy, F., Hebbeln, D., and Wefer, G.: Terrigenous sediment supply along the Chilean continental margin: modern regional patterns of texture and composition, Geol. Rundsch., 87(3), 477494, 1998.

Lamy, F., Hebbeln, D., and Wefer, G.: High-resolution marine record of climatic change in mid-latitude Chile during the last 28000 years based on terrigenous sediment parameters, Quaternary Res., 51(1), 83-93, 1999.

Laursen, J. and Normark, W. R.: Late Quaternary evolution of the San Antonio Submarine Canyon in the central Chile forearc, Mar. Geol., 188(3-4), 365-390, 2002.

Lohrmann, J., Kukowski, N., Krawczyk, C. M, Oncken, O., Sick, C., Sobiesiak, M., and Rietbrock, A.: Subduction Channel Evolution in Brittle Fore-Arc Wedges - a Combined Study with Scaled Sandbox Experiments, Seismological and Reflection Seismic Data and Geological Field Evidence, in: The Andes Active Subduction Orogeny, Frontiers in Earth Sciences, Berlin Heidelberg, Springer, 237-262, 2006.

Martin, M., Kato, T. T., Rodriguez, C., Godoy, E., Duhart, P., McDonough, M., and Campos, A.: Evolution of the late Paleozoic accretionary complex and overlying forearc-magmatic arc, south central Chile (38 degrees-41 degrees S): Constraints for the tectonic setting along the southwestern margin of Gondwana, Tectonics, 18(4), 582-605, 1999.

Melnick, D., Bookhagen, B., Strecker, M. R., and Echtler, H. P.: Segmentation of megathrust rupture zones from forearc deformation patterns over hundreds to millions of years, Arauco peninsula, Chile, J. Geophys. Res., 114, B01407, doi:10.1029/2008JB005788, 2009.

Melnick, D. and Echtler, H. P.: Inversion of forearc basins in southcentral Chile caused by rapid glacial age trench fill, Geology, 34(9), 709-712, 2006.

Mulder, T. and Cochonat, P.: Classification of offshore mass movements, J. Sediment. Res., 66(1), 43-57, 1996.

Muñoz, P., Lange, C. B., Gutiérrez, D., Hebbeln, D., Salamanca, M. A., Dezileau, L., Reyss, J. L., and Benninger, L. K.: Recent sedimentation and mass accumulation rates based on ${ }^{210} \mathrm{~Pb}$ along the Peru-Chile continental margin, Deep Sea Res., 51, 2523-2541, 2004.

Neteler, M. and Mitasova, H.: Open Source GIS: A GRASS GIS Approach. Bd. 773, Boston, Kluwer Academic Publishers, 2004.

Prior, D. B. and Coleman, J. M.: Submarine landslides: Geometry and nomenclature, Z. Geomorphol., 23(4), 415-426, 1979.

Raitzsch, M., Völker, D., and Heubeck, C.: Sedimentary and mass waste processes on the slope off South Central Chile inferred from dredge samples, Mar. Geol., 244(1-4), 166-183, 2007.

Ranero, C. R., von Huene, R., Weinrebe, R. W., and Reichert, C.: Tectonic Processes along the Chile Convergent Margin, in: The Andes - Active Subduction Orogeny, edited by: Oncken, O., Chong, G., Franz, G., Giese, P., Götze, H.-J., Ramos, V. A., Strecker, M. R., and Wigger, P., Frontiers in Earth Sciences, Springer, Berlin Heidelberg, 91-123, 2006. 
Rehak, K., Strecker, M. R., and Echtler, H. P.: Morphotectonic segmentation of an active forearc, $37^{\circ} \mathrm{S}-41^{\circ} \mathrm{S}$, Chile, Geomorphology 94(1-2), 98-116, 2008.

Reichert, C. and Scientific Shipboard Party: Cruise Report SO161 leg $2 \& 3$ - SPOC Subduction processes off Chile: preliminary geophysical results of SONNE cruise SO-161(2+3), 2002.

Rodrigo, C., González-Fernández, A., and Vera, E.: Variability of the bottom-simulating reflector (BSR) and its association with tectonic structures in the Chilean margin between Arauco Gulf $\left(37^{\circ} \mathrm{S}\right)$ and Valdivia $\left(40^{\circ} \mathrm{S}\right)$, Mar. Geophys. Res., 30, 1-19, 2009.

Röser, G.: Petrography, physical properties, and geotechnical behavior of modern sediments, Southern Chile Trench, phD Thesis, Albert-Ludwigs-Universität Freiburg im Breisgau, Freiburg im Breisgau, 149 pp., 2007.

Shipboard Scientific Party: Leg 202 summary, in: Proceedings of the Ocean Drilling Program, edited by: Mix, A. C., Tiedemann, R., Blum, P., et al., Proc. ODP, Init. Repts., 202: College Station, TX (Ocean Drilling Program), 1-145, doi:10.2973/odp.proc.ir.202.101.2003, 2003.

Synolakis, C. E., Bardet, J. P., Borrero, J. C., Davies, H. L. ,Okal, E. A., Silver, E. A., Sweet, S., and Tappin D. R.: The slump origin of the 1998 Papua New Guinea Tsunami, P. Roy. Soc. London, 458, 2020, 763-789, 2002.

Tappin, D. R., Watts, P., McMurtry, G. M., Lafoy, V., and Matsumoto T.: The Sissano, Papua New Guinea tsunami of July 1998 - offshore evidence on the source mechanism, Mar. Geol., 175(1-4), 1-23, 2001.

Thornburg, T. M. and Kulm, L. D.: Depositional-Environments and Sedimentary Processes in Chile Trench, AAPG BulletinAmerican Association of Petroleum Geologists, 67(3), 557-558, 1983.
Thornburg, T. M., Kulm, L. D., and Hussong, D. M.: SubmarineFan Development in the Southern Chile Trench - a Dynamic Interplay of Tectonics and Sedimentation, Geol. Soc. Am. Bull., 102(12), 1658-1680, 1990.

Völker, D.: A simple and efficient GIS tool for volume calculations of submarine landslides, Geol.-Mar. Lett., submitted, 2009.

Völker, D., Wiedicke, M., Ladage, S., Gaedicke, C., Reichert, C., Rauch, K., Kramer, W., and Heubeck, C.: Latitudinal Variation in Sedimentary Processes in the Peru-Chile Trench off Central Chile, in: The Andes - Active Subduction Orogeny, Frontiers in Earth Sciences, Berlin Heidelberg, Springer, 193-216, 2006.

Völker, D., Reichel, T., Wiedicke, M., and Heubeck, C.: Turbidites deposited on Southern Central Chilean seamounts: Evidence for energetic turbidity currents, Mar. Geol., 251, 15-31, 2008.

von Huene, R., Corvalan, J., Flueh, E. R., Hinz, K., Korstgard, J., Ranero, C. R., Weinrebe, R. W., and the CONDOR scientists: Tectonic control of the subducting Juan Fernandez Ridge on the Andean margin near Valparaiso, Chile, Tectonics, 16(3), 474 488, 1997.

Watts, P., Grilli, S. T., Tappin, D. R., and Fryer, G. J.: Tsunami generation by submarine mass failure. II: Predictive equations and case studies, J. Waterw. Port. C-ASCE, 131(6), 298-310, 2005.

Wessel, P. and Smith, W. H. F.: New, improved version of the Generic Mapping Tools released, EOS Trans. AGU, 79, p. 579, 1998.

Willner, A. P., Thomson, S. N., Kroner, A., Wartho, J. A., Wijbrans, J. R., and Herve, F.: Time markers for the evolution and exhumation history of a Late Palaeozoic paired metamorphic belt in north-central Chile (34 degrees-35 degrees 30' S), J. Petrol., 46(9), 1835-1858, 2005. 